\title{
"The Grandest Railroad Project of the Age"
}

Donovan L. Hofsommer

THE STATE OF IOWA WAS THE SCENE OF INTENSE RAILROAD activity during the mid-nineteenth century. Most early efforts were fostered by companies which desired to link Chicago and the East with the new transcontinental road in Nebraska Territory. The building of these east-west, or horizontal, roads was followed by a second flurry of construction which had as its purpose the connection of prominent middle western cities lying to the north and to the south of Iowa. The efforts to build a series of east-west roads across the state, and to overlay them in grid fashion with north-south, or vertical, lines was the opening chapter in Iowa's railroad era. Not surprisingly, the successfully completed railroads of the era have repeatedly drawn the attention of historians, while the ventures that failed to come to fruition have not. One such, the Iowa Central Railroad-an enterprise designed to link the Hawkeye State with St. Louis on the south and St. Paul on the north-deserves investigation. It was enthusiastically hailed in hyperbole by its promoters as "the grandest railroad project of the age." It promised much but in the end was "grand" only in its failure as the most important of the proposed vertical railroads across Iowa. ${ }^{1}$

'Portions of this study were used in a paper entitled "Steam Railroad Promotion: The Case of the Iowa Central Railroad," read before the Northern Great Plains History Conference at the University of Wisconsin-La Crosse in 1976. The Iowa Central Railroad should not be confused with either the Iowa Central Railway, an operating company which passed to the Minneapolis \& St. Louis Railroad in 1912, or the Iowa Central Air Line Railroad, a paper company. On the Iowa Central Railway, see Donovan L. Hofsommer, "A History of the Iowa Central Railway" (unpublished M.A. Thesis. Cedar Falls: University of Northern Iowa, 1966). On the M\&StL, see Frank P. Donovan, Jr., Mileposts on the Prairie: The Story of the Minneapolis \& St. Louis Railway (New York: Simmons-Boardman, 1950). On the Iowa Central Air Line see Robert J. Casey and W. A. Douglas, Pioneer Railroad: The Story of the Chicago and North Western System (New York: McGraw-Hill, 1948), 124-125, and Ruth I. Preston,' "The Lyons and Iowa Central Railroad," Annals of Iowa. IX (January 1910), 284-301. 
Precursor to the Iowa Central Railroad was the aptly named St. Louis, Iowa \& St. Paul Railway. The goals of the company were clearly implied in its title-to join St. Louis with St. Paul over a route serving the Iowa communities of Oskaloosa, Toledo, and Cedar Falls. Interest along the projected road was understandably keen. As one writer put it, "such a road would supply central Iowa with its two greatest needs, coal from southern Iowa and cheap building material from Minnesota." Nevertheless, the Panic of 1857, the Civil War, and the subsequent secession depression all combined to forestall construction. Correspondingly the company lost its franchise before a single rail had been laid. ${ }^{2}$

Interest in a north-south road through central Iowa did not flag, however. Even before the Civil War ended, a new company-the Iowa Central Railroad-was formed on January 5, 1865. The road was capitalized at $\$ 6$ million; headquarters were to be in Oskaloosa. Its charter called for the construction and operation of a railroad reaching from the terminus of the North Missouri Railroad on the southern border of Iowa to a connection with the Cedar Falls \& Minnesota Railroad (CF\&M) at Cedar Falls. The company's first president was one of its earliest and most energetic boosters-David Morgan, a resident of New Sharon, Iowa. ${ }^{3}$

Morgan was particularly optimistic during the summer of 1865 . He had good reason. Risk capital was increasingly available, there was expanding public confidence in railroad matters, and there was general local support for the project. The sale of Iowa Central stock commenced during that same season; volume was strong. Moreover, there was good news from both Minnesota and Missouri. Rails of the Minnesota Central Railway already extended some seventy miles to the south of St. Paul, and construction on the remaining portion would soon close the gap to the Iowa border. To the south, the North Missouri Railroad was already operating trains over 170 miles

${ }^{2}$ Organization and Articles of Incorporation of the Iowa Central R. R. Co. (Des Moines: lowa State Register Printing, 1866), 5. Available at the University of Iowa Library, Iowa City. Hereafter referred to as Organization . . Iowa Central R. R.; Charles E. Payne, Josiah Bushnell Grinnell (Iowa City: State Historical Society of Iowa, 1938), 61.

${ }^{3}$ Luella M. Wright, Peter Melendy (Iowa City: State Historical Society of Iowa, 1943), 225; Organization . . . Iowa Central R. R., 5. 
of completed trackage between St. Louis and Macon, Missouri. Only a brief construction drive would be necessary to bring its service to the Iowa frontier. To be sure, the large gap on the St. Louis-St. Paul route was in Iowa where only the fifteen miles between Cedar Falls and Waverly, operated by the Cedar Falls \& Minnesota Railroad, were already in service. ${ }^{4}$

There were manifold arguments offered in support of the Iowa Central project. These ranged from purely local purposes to important regional considerations. Communities such as Oskaloosa and Montezuma-which had been passed by when the horizontal trunk carriers had pushed west-were looking to a north-south venture as a means by which they might gain rail service. Others, like Cedar Falls and Grinnell, saw the Iowa Central as an agency of competition for the eastwest roads which already served them. Yet the capstone argument for all advocates was that this road would be an integral part of what Peter Melendy, an early booster and official of the company, referred to as "the grandest railroad project of the age"an interregional railroad linking St. Louis with St. Paul. ${ }^{5}$

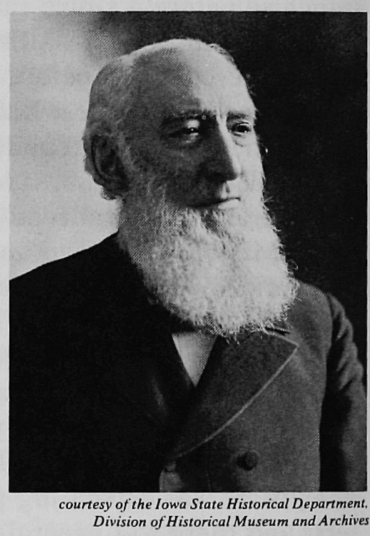

Peter Melendy

During the summer of 1865 the editor of the Cedar Falls Gazette wondered who, if anybody, could be "stupid enough to fear that the Iowa Central will not be built, when the people of Iowa from Cedar Falls to the State line [of Missouri] are bleeding so outrageously from the monopolies of heartless railroad corporations?" These corporations were, of course, the "eastern" horizontal trunk carriers. Iowa Governor William M. Stone apparently concurred. In his judgement, the rail-

${ }^{4}$ Wright, Peter Melendy, 226-234.

${ }^{5}$ Cedar Falls [Iowa] Gazette, April 20, 1866; Wright, Peter Melendy, 248; Organization Iowa Central R. R., 25. 
road corporations had an "immoderate thirst of monopolizing the avenues of transportation, and their exorbitant charges for carrying stock and grain [rendered them] formidable enemies" to Iowa's agricultural prosperity. Governor Stone was against the growth of railroad combinations that might accrue too much power and wealth; but as leader of a prospering farming state, he saw the obvious benefits of a network of railroad lines operating in Iowa. He believed, "To encourage and

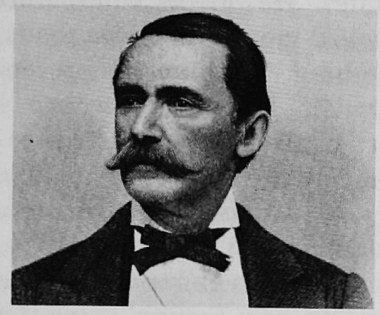

courtesy of the Iowa State Historical Department. Division of Historical Museum and Archives

Governor William Stone foster our railroad enterprises by every feasible means is manifestly the part of wisdom." The condition to be avoided, of course, was dependency on one road, particularly if it happened to be one of the "eastern" trunks. One Iowa editor enunciated a suggestion which met with general approval from residents of the state. For the residents of Iowa's heartland, said he, the "only permanent remedy" was the "establishment of competing lines"-preferably "competing lines with different terminal points." Clearly there was potential utility for any north-south road in Iowa, for it would cross every eastwest trunk, thus offering its patrons a variety of gateway options. Such a road would, correspondingiy, foster competition among these various Chicago-based trunk roads. This should result in reduction of freight and passenger tariffs, a circumstance highly desired by users of the roads. ${ }^{6}$

Chicago, or at least the perceived nefarious activities of its merchants and railroad men, was at the heart of much of the north-south railroad sentiment in Iowa. The editor of the Cedar Falls Gazette was convinced that citizens had been victimized by business interests in Chicago. He felt that the

'Organization . . . Iowa Central R. R., 12-13; Cedar Falls Gazette, Julv 14, 1865, August 11,1865 , January 12, 1866, March 22, 1867, February 4, 1870; Benjamin F. Shambaugh, editor, Messages and Proclamations of the Governors of Iowa. Seven Volumes (Iowa City, 1903), III, 56-57; cf. George H. Miller, “Origins of the Iowa Granger Law," The Mississippi Valley Historical Review, Vol. XL, No. 4 (March 1954), 657-680, especially 662-665. 
Chicago railroads and produce buyers had been engaged in the "pernicious practice of deceiving the people of Iowa, in various respects, in the purchase of the surplus products of the state." He further complained that "Chicago interests" controlled most of the Iowa roads, and, in his judgement, they left nothing "undone to prevent shipments to and from St. Louis." The only answer to the problem then, was a road to St. Louis; this would reduce the dependence on Chicago by placing the market of St. Louis in direct competition with it.?

A St. Louis outlet-it would "at once place in competition for our trade the two greatest grain markets in the world, and place us in a commanding position, instead of the subservient one we now occupy"-insisted the Gazette editor. Moreover, railroad communication with St. Louis would assure that merchants of mid-Iowa would be able to sell most goods as inexpensively as those purveyed currently by Chicago merchants. Farmers, too, would benefit. They had traditionally found a more profitable market in St. Louis. Farmers calculated that with an all-rail route to St. Louis they would gain from fifteen cents to twenty-five cents per bushel of grain than they were receiving currently in Chicago. ${ }^{8}$

Iowa Central promoters consistently hammered on a recurring theme: rival railroads-especially if Chicago-based or tied only to that outlet-were inadequate; what was required were rival railroads serving rival cities. Competition was the answer. The editor of the Gazette put it simply: "Competition is the only panacea for all monopolies." In evidence he quoted carload rates to Chicago from Mount Pleasant and Ottumwa, both stations on the Burlington \& Missouri River Railroad. The rate from Mount Pleasant to Chicago-233 miles-was $\$ 72.00$; the rate from Ottumwa to Chicago- 280 miles-was $\$ 60.00$. The difference, he said, was explained by the fact that

Cedar Falls Gazette, July 7, 1865, August 11, 1865, January 5, 1866, February 8, 1867; Organization . . Iowa Central R. R.. 15-16. For an assessment of this rivalry see Wyatt Winton Belcher. The Economic Rivalry Between St. Louis and Chicago, 1850-1880 (New York: Columbia University Press, 1947).

${ }^{8}$ Organization. . . Iowa Central R. R., 11-13; Cedar Falls Gazette. July 7, 1865. August 25, 1865. See also Earl S. Beard, "Local Aid to Railroads in Iowa," Iowa Journal of History. Vol. 50, No. 1 (January 1952), 1-34, especially 19-22. 
“The Grandest Railroad Project of the Age"

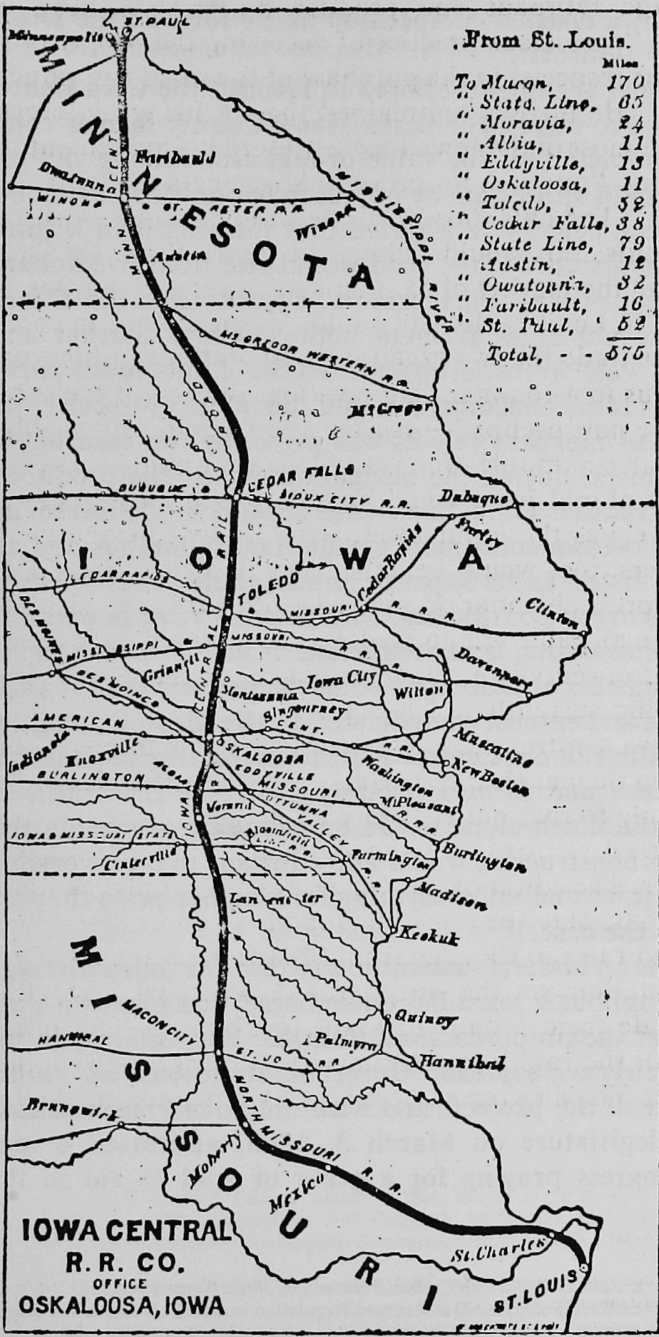

courtesy of the author

The proposed route of the Iowa Central Railroad. 
Ottumwa boasted competition in the form of the Des Moines Valley Railroad. ${ }^{9}$

Other arguments offered in favor of the Iowa Central were not tied to rates. One Black Hawk County farmer contended, for instance, that the value of real estate along the proposed line would appreciate by no less than one-third as soon as construction began. He asserted that farming land within a convenient distance of the road would rise from five dollars to ten dollars per acre. Furthermore, according to the Gazette, the road would allow farmers both a winter market and yearround water transportation from St. Louis to all parts of the globe; Iowa consumers would be able to receive southern goods as inexpensively as was presently the case for Chicago consumers; during the navigation season the products of the industrialized Ohio River valley could be delivered inexpensively to Iowa consumers via St. Louis; lumber and the products of the Lake Superior mines could be efficiently transported to Iowa customers; with the new road in operation, the time consuming and inefficient need for breaking bulk or ferrying cars at Dubuque would be negated; the Iowa Central was a local enterprise dedicated to the idea of doing for Iowa what the Illinois Central had done for Illinois; the traffic in Mahaska and Monroe County coal plus the traffic in pine from the north alone would be adequate to sustain the road; and its construction would allow Iowans to buy everything at a lower price and sell everything for a higher price than was currently the case. ${ }^{10}$

It is an understatement to say that the journalist was exaggerating, but it must be remembered that his town was in the path of the proposed Iowa Central. Yet, interest in the road was fairly widespread. Governor Stone was an enthusiastic backer of the project, and with only one vote in dissent, the Iowa legislature on March 3, 1866, addressed a memorial to Congress praying for a grant of land to aid in the con-

${ }^{9}$ Cedar Falls Gazette, July 7, 1865, February 8, 1867, November 1, 1867. See also Earl S. Beard, "The Background of State Railroad Regulation in Iowa," Iowa Journal of History, Vol. 51, No. 1 (January 1953), 1-36, especially 20.

${ }^{10}$ Cedar Falls Gazette, July 7, 1865, August 11, 1865, March 22, 1867, October 25, 1867; Organization . . . Iowa Central R. R., 12-13. 
struction of the road. The legislators emphasized that a northsouth road would engender competition and thus reduce rates: "It would be the best regulator of excessive tariffs." Grandiosely they saw in the Iowa Central an important link in a "great chain of railroad from the lakes of the north to the Gulf on the south," having its northern terminus at Superior City and its southern terminus at Galveston, tapping both St. Louis and St. Paul, and, incidentally, serving Iowa as it bridged the state on a vertical axis. On March 28, 1866, the memorial was dutifully referred to the Committee on Public Lands in the House of Representatives. Representative Josiah B. Grinnell told W. T. Smith, who had succeeded David Morgan as president of the Iowa Central, that he thought the Congress would act affirmatively. ${ }^{11}$

Meanwhile, the president of the Minnesota Central Railway assured officials of the Iowa Central that a connection of the two roads was "regarded as of the first importance" by his company. Govenor William R. Marshall similarly assured Iowa Central officials of Minnesota's interest in the road. That state's aspirations were similar to Iowa's: securing a direct allweather route to St. Louis; securing access to southern as well as world markets; and securing a competing line to Chicago and the East. All of this was gratifying, but firm support from the South was even more important to the success of the Iowa Central venture. ${ }^{12}$

The leading citizens of St. Louis had not been unmindful of the Iowa Central and its potential benefit to them. They knew that during the Civil War considerable trade from the North had been lost by St. Louis to Chicago, and they knew that Chicago-based railroads had facilitated much of this. St. Louis interests now hoped to recapture this trade, and some of them anticipated that the Iowa Central could be the prime

"Ibid., 12-13, 20; Cedar Falls Gazette, March 9, 1866, March 23, 1866, April 13, 1866, May 4, 1866; U.S. House of Representatives, 39th Congress, 1st Session, 1865-1866, Miscellaneous Documents. Three Volumes (Washington: Government Printing Office, 1866), III, Mis. Doc. No. 76 (n.d.).

${ }^{12}$ S. Chamberlain, president, Minnesota Central Railway, March 5, 1866, to Peter Melendy, vice president, Iowa Central Railroad, a letter reproduced in the April 27, 1866 issue of the Cedar Falls Gazette; William R. Marshall, governor of Minnesota, May 19, 1866, to Peter Melendy, vice president, Iowa Central Railroad, a letter reproduced in the June 1, 1866 issue of the Cedar Falls Gazette; Wright, Peter Melendy, 248. 
mover in that effort. The St. Louis Democrat reflected that sentiment:

\begin{abstract}
The people of this city especially have reason to look with much interest to the field of business enterprise which a railroad communication with Iowa would open up. There is no part of the country where a larger share of agricultural wealth will be located. ... Our merchants will do well to give their closest attention to the matter, being assured beyond all contingency that whatever they may contribute in the way of material aid to secure an early railroad communication with our Iowa neighbors will all come back to them with liberal interest. ${ }^{13}$
\end{abstract}

At a meeting of Iowa Central boosters in Oskaloosa on April 27, 1865, a decision was made to send a delegation to St. Louis. The delegation was warmly received on June 21 at a meeting with over 150 railroad men and other St. Louis capitalists at the Lindell Hotel. Colonel Daniel Anderson of Monroe County assured his hosts that Iowans would completely grade and tie the road without outside help. He also reminded them of the benefits which would accrue to them by linking Iowa to an all-season waterway at St. Louis. The St. Louis businessmen confirmed their interest in the road as a means of securing the trade of the rich valleys of the Des Moines and Cedar Rivers, and of developing the immense agricultural markets of Iowa. One of the resolves of the meeting was that the city of St. Louis and the state of Missouri collectively promised to do their parts in binding Iowa and Missouri together by railroads. The president of the North Missouri Railroad, Isaac $\mathrm{H}$. Sturgeon, reminded all that peace had come, that slavery was dead, and that St. Louis was alive to her opportunities. He also pledged his personal efforts and the corporate efforts of his railroad to assist the Iowa Central. ${ }^{14}$

The Iowa delegation returned to the Hawkeye State in a buoyant mood. Its members reported that they had had every encouragement and assurance from the board of directors of the North Missouri Railroad. More importantly, the delegates announced that the Missouri firm would stand ready to offer

${ }^{13}$ Cedar Falls Gazette, September 1, 1965; St. Louis Democrat, undated article reproduced in the Cedar Falls Gazette. July 21, 1865.

${ }^{14}$ Cedar Falls Gazette, June 30, 1865; Organization . . Iowa Central R. R., 12-13. 
material aid when needed to assist in the completion of the road. ${ }^{15}$

Such news was adequate to set off a wave of excitement all along the proposed route. Enthusiasm reached its zenith when officials of the Iowa Central announced that a ground-breaking ceremony was scheduled for Cedar Falls on September 19. It proved to be a gala celebration. The streets were crowded with spectators who were anxious to applaud the 1,500 parade participants and-to be sure-the reason for the parade itself. The bandwagon was particularly well received; on its sides there flamed in red capital letters the words "Iowa Central." In the procession or along its route were a number of people waving banners proclaiming a variety of timely mottoes:

"The Lakes And Gulf Have Met, Shook Hands, And Vowed Eternal Friendship",

"The New Trinity-Minnesota, Iowa, and Missouri"

"The Direct Route To All Parts Of The Old World Is The Iowa Central Via St. Louis"

"The Strongest Ties Between North and South Are The Iowa Central Ties"

"The Roads That Pay-New York Central, Michigan Central, Illinois Central, and Iowa Central"

The procession moved south-symbolically toward Missouriwhere, at the edge of town, dirt was turned to initiate construction of the Iowa Central Railroad. Thereafter followed the customary speeches, feasting, and that evening a grand ball completed the celebration. ${ }^{16}$

Soon there was evidence of the impact which the project had made on the area populace. At Cedar Falls, store fronts advertised the Iowa Central Hall of Fashions, the Iowa Central Iron Works, and the Iowa Central Agricultural Warehouse \& Seed Store. Meanwhile, local musicians organized the Iowa Central band. There was also more important evidence of the project. Indeed, a contract was let on the grading and bridging of the first ten miles south from Cedar Falls. It was followed by another on November 1 , in Tama County, for the

${ }^{16}$ Cedar Falls Gazette, September 22, 1865; Wright, Peter Melendy, 237-239. 
road north of Toledo toward Cedar Falls. Of particular note was the news that Tama County voters had approved a $\$ 40,000$ bond issue in favor of the Iowa Central, and had further agreed to grant the road some 30,000 acres of the county's swamp lands. At about the same time, voters in Appanoose County voted bonds in the amount of $\$ 50,000$ plus considerable swamp land scrip. ${ }^{17}$

As the year 1865 came to a close, progress reports remained favorable. The supporters of the road were especially encouraged when they learned that the North Missouri Railroad was being surveyed northward from Macon to the Iowa border. And president Sturgeon of the Missouri company had reminded an official of the Iowa Central in a letter that his road had full faith in the Iowa firm. There was no mention in the letter of any financial support for the Iowa Central, however. It seemed to matter little in that happy Christmas season of $1865 .^{18}$

During the next year officials of the Iowa Central continued to seek support for the St. Louis-St. Paul railroad"one of the great wants of the state," according to Peter Melendy, the firm's vice president. Melendy's assertion was well founded: eighty-three of Iowa's most prominent men had recently signed a memorial "To the Capitalists of Saint Louis: Iowa Central Railroad-Why It Should Be Built." It had a most desirable effect. The North Missouri's board of directors responded by adopting the following resolution:

The North Missouri Railroad hereby pledges itself to extend every facility tending to encourage the success of such enterprise. .... It will aid, assist and give its influence in behalf of the Iowa Central Railroad. . . . We regard it as one of the most important railway enterprises to St. Louis. . . This company will, so far as it may have any ability to do so, aid in the purchase of iron for the track of said railroad, and the equipping of it with rolling stock, and that it will not in its business or time-tables, discriminate against the Iowa Central in favor of any other railroad.

${ }^{17}$ Organization . . Iowa Central R. R., p. 5; Cedar Falls Gazette, September 15, 1865 , November 3, 1865, November 10, 1865, September 7, 1866, September 28, 1866, March 1, 1867.

${ }^{18}$ Wright, Peter Melendy, 241; Oskaloosa [Iowa] Herald, an undated article appearing in the Cedar Falls Gazette, December 22, 1865. 
Perhaps with this in mind, A. D. Barnum, general agent for the Iowa Central, wrote to an on-line editor advising him that "Everything looks favorable and is working well for the Iowa Central Railroad-The Grand Trunk Railway of the West?' 19

The news from St. Louis was heartily endorsed along the route of the Iowa road. At Albia participants at a promotional meeting agreed that the time had come for energetic action in support of the road. Farther north, eighty-nine men and thirty teams labored on the first ten miles of grade out of Cedar Falls. And in June, 1866, a second ground-breaking ceremony was held on the Iowa-Missouri border. Iowa Central President Smith stood with one foot in Missouri and the other in Iowa, and with a single scoop of his shovel turned soil of the two states. The postwar recovery continued; all looked well. In July a rumor to the effect that Jay Cooke \& Co. was interested in the project floated along the line. By December, the village of Eddyville had fulfilled its subscriptions, and a contract was let for the right-of-way between that community and the Missouri border. The entire route of the Iowa Central had been surveyed, except for that portion of it in Poweshiek County where various parties were yet contesting for the road. By the end of 1866 , ninety percent of the 151 miles between Cedar Falls and the Missouri frontier was under contract, and thirtyeight miles were ready for ties. ${ }^{20}$

Yet all was not well. The Cedar Falls \& Minnesota Railroad, with which the Iowa Central expected to connect at Cedar Falls as a part of the St. Louis-St. Paul route, had come under the influence of the Dubuque \& Sioux City Railroad (D\&SC), an east-west road, and, in fact, the CF\&M was leased to the D\&SC on September 22, 1866. For that matter, the D\&SC itself would be leased to the Chicago-based Illinois Central Railroad on October 1, 1867. All of this frightened the promoters of the Iowa Central because they feared that "foreigners" might throttle the local road, and in the process, sub-

${ }^{19}$ Organization . . I Iowa Central R. R., 12-13; Cedar Falls Gazette, April 13, 1866, June 1, 1866; George W. Blood, Secretary of the North Missouri Railroad, March 15, 1866, to William P. Smith, President of the Iowa Central Railroad, a letter reproduced in the Cedar Falls Gazette, March 20, 1866.

${ }^{20}$ Albia [Iowa] Union, May 17, 1866; Oskaloosa Herald, June 28, 1866; Cedar Falls Gazette, May 25, 1866, July 27, 1866, November 30,1866, December 7, 1866, December 28, 1866. 


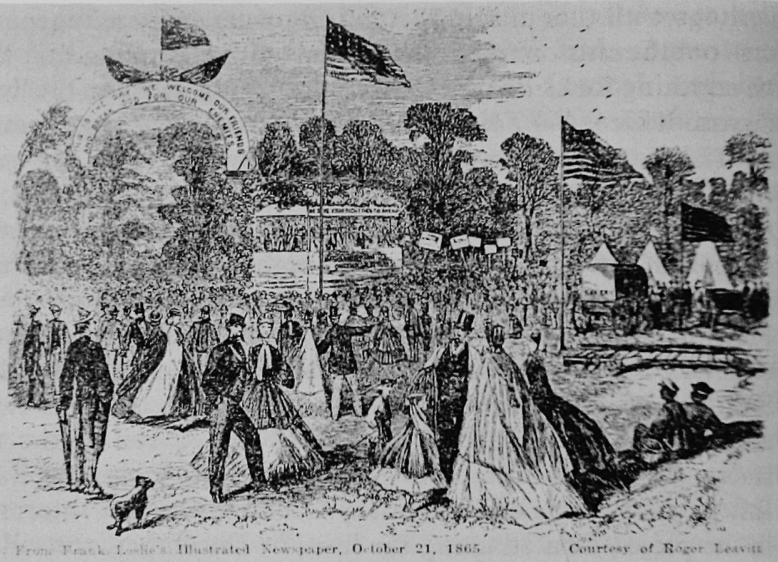

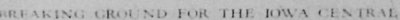

courtesy of the author

The ground-breaking ceremonies at Cedar Falls were significant enough to gain the attention of Frank Leslie's Illustrated Newspaper.

vert the purposes of the St. Louis-St. Paul route. To avoid potential difficulties in interchanging traffic with an unfriendly carrier for the Cedar Falls-Minnesota border segment, the Iowa Central Railroad Construction Company was formed on April 16, 1866. Capitalized at $\$ 6$ million, it was authorized to construct, maintain, and operate a railroad from Cedar Falls to a connection with the Minnesota Central Railroad at or near the Iowa-Minnesota border. The Iowa Central Railroad Construction Company was independent from the Iowa Central Railroad, but many of its directors were also associated with the latter firm, and it was clearly a puppet. The entire distance from Iowa's northern border to its southern border now would be in the hands of a single friendly carrier, but the need to protect the northern connection added seventy-seven more route-miles and, concomitantly, the necessity of seeking even more funding. ${ }^{21}$

${ }^{21}$ State of Iowa, Report of the Board of Railroad Commissioners for the Year Ending June 30, 1896 (Des Moines: State Printer, 1897), 220-221; Cedar Falls Gazette, May 4, 1866, June 15, 1866, May 3, 1867; "Articles of Incorporation of the Iowa Central Railroad Construction Company," available at the Iowa Secretary of State's office, Des Moines. 
“The Grandest Railroad Project of the Age"

Regretfully for the Iowa Central, problems on the north were not the only ones it faced. As early as the summer of 1865 the editor of the Cedar Falls Gazette had observed that it "was unreasonable to suppose that a great central road will be built across Iowa without much clashing of localities, and much wire-pulling and hard work for the furtherance of public and private interests of various sections." He might have added that not all Iowa communities favored the Iowa Central project. River cities, Dubuque in particular, did not, for they stood to lose much in water traffic if the railroad was built. Neither did Cedar Falls' arch rival, nearby Waterloo, favor the road, for the Iowa Central would not pass through it. Ottumwa citizens favored a St. Louis-St. Paul route via Bloomfield, Ottumwa, Sigourney, Marengo, Cedar Rapids, Waterloo, and thence over to CF\&M to a junction with the Minnesota Central. The management of the Iowa Central had expected this disharmony, but had assumed that its early and impressive head start plus its obvious and logical "air line" route would be adequate to forestall potential competition. ${ }^{22}$

It quickly appeared that events would conspire otherwise. On September 27, 1865, the St. Louis \& Cedar Rapids Railway Company (StL\&CR) was organized for the purpose of building a line of railroad from the North Missouri's end-oftrack at Coatsville, on the Iowa-Missouri border, to Cedar Rapids. There it would presumably connect with the Cedar Rapids \& St. Paul Railway, chartered at about the same time. One can only guess as to the true intentions of the StL\&CR's promoters. Some may have cared only about stopping the Iowa Central. Some may have merely hoped to put communities such as Ottumwa and Cedar Rapids on a St. Louis-St. Paul route. Others, like StL\&CR President J. P. Farley of Dubuque County, may have wanted only to protect the interests of the river communities. Still others may have been protecting the interests of Chicago-based trunk roads. ${ }^{23}$

Iowa Central President William T. Smith initially took all of this in stride. But by the late spring of 1866 he was urging

${ }^{22}$ Cedar Falls Gazette, August 4, 1865, August 11, 1865, September 1, 1865.

${ }^{23}$ State of Iowa, Report of the Board of Railroad Commissioners for the Year Ending June 30, 1880 (Des Moines: State Printer, 1880), 246-247; Report . . 1896, 186-187. 
that a concerted, single effort be made to put the Iowa Central project through to fruition. Correspondingly he counseled that it would prove disastrous to proliferate affections and energies. By summer there were those in Iowa and in St. Louis who argued that it would not pay to build both the Iowa Central and the StL\&CR. The indefatigable Smith asserted that, on the contrary, there was abundant room for a north-south road, east of the Iowa Central along or close to the Mississippi River. On the other hand, he worried that citizens of St. Louis might confuse the Iowa Central project with the StL\&CR venture-a venture which he increasingly believed was initiated solely for the purpose of killing the Iowa Central. The ultimate advantage to St. Louis and to all of Iowa was, he asserted, the Iowa Central-a road which would connect St. Louis with St. Paul, tap the heartland of Iowa, and cross every east-west trunk line enroute. Chicago, he pointed out in a letter to the editor of the Missouri Republican, had "built railroads into Iowa, while your city has not a single connection of this kind in this direction, and if you do not soon secure facilities for intercourse with our people, our temporary trade will become a confirmed necessity. . . ." ${ }^{24}$

Certain St. Louis journalists viewed it similarly. One of them, a writer for the St. Louis Times, predicted that "completion of the road from St. Louis to the Minnesota state line would increase the business of this city by at least one-third." The editor of the St. Louis Republican concurred: The Iowa Central "lets St. Louis into the very heart of Iowa" and "crosses grand arterial roads by which our city will be placed in railroad connection with every portion of Iowa, and with Nebraska. It will bring Minnesota to our door.” 25

During the summer of 1867 there was apparent reassurance from the North Missouri Railroad. It was in the process of changing its gauge from 5 ' 6 " to the standard $4{ }^{\prime} 8^{1 / 2}$ ", thus promising that cars from a northern connection could be interchanged with it. Additionally there was news that the com-

${ }^{24}$ Cedar Falls Gazette, April 13, 1866, April 27, 1866, June 8, 1866, July 27, 1866, December 28, 1866. Cf. Miller, "Origins of the Granger Law," 670 .

${ }^{25}$ St. Louis Times, an undated story reproduced in the Cedar Falls Gazette, May 3, 1867; St. Louis Republican, October 18, 1867, a story reproduced in the Cedar Falls Gazette, October $25,1867$. 
pany had 2,500 men working on its sixty-eight mile extension from Macon to the Iowa frontier. They were reportedly laying no less than one mile of track per day. It all represented good news for the Iowa Central. ${ }^{26}$

There was at the same time good news from the Iowa Central itself. By July, 1867, all of the grading had been completed in Black Hawk County, most of it had been completed in Tama County, and the entire sixty-one mile stretch of rightof-way between Oskaloosa and the Missouri border was under contract-one-third of it had been graded. The editor of the Cedar Falls Gazette was predictable in his enthusiasm: "Be patient gentlemen, the Iowa Central is not so far in the future as you might think. Stand ready for the first trip to St. Louis." Additional good news flowed from the pen of Iowa Central President Smith. On May 3, he told the editor of the St. Louis Times that the long section between the Missouri border and Cedar Falls would be graded and bridged by November. That same section, he continued, would be tied during the winter, and rails for it would be put down in the spring of 1868 . Meanwhile, surveyors would be in the field between Cedar Falls and the Minnesota border; contracts for that section would be let in a few months. Smith asserted that with this work done it would be hard to negotiate the road's bonds. By late summer that seemed confirmed. On September 5, 1867, the Iowa Central board met in Oskaloosa to award a contract to Champlin, Balch \& Co. of St. Louis-contractors for the North Missouri Railroad-for the swift completion of the road to Cedar Falls. That contract also provided for necessary rolling stock. The board further announced that it was negotiating for the required iron rails. Everything seemed upbeat as the year ended. ${ }^{27}$

Yet the passing of 1867 marked the end of good news for the Iowa Central. Its promoters had long boasted that the road would be built without outside help. That proved to be an

${ }^{26}$ William Swartz, "The Wabash Railroad," Railroad History (Fall 1975), 33; Cedar Falls Gazette, September 13, 1867.

${ }^{27}$ Cedar Falls Gazette, March 22, 1867, July 12, 1867, September 13, 1867. An undated letter from President William T. Smith to the editor of the St. Louis Times reproduced in the Gazette, May 3, 1867; St. Louis Republican, an undated story reproduced in the Gazette, November 8,1867 . 
impossible dream. As early as May, 1867, the Iowa Central management had asked St. Louis interests for assistance in the amount of $\$ 175,000$. One booster said simply: "Money is what will complete the road." In the summer of 1868 a delegation from Iowa specifically asked the citizens of St. Louis to make funds available through the Merchant's Exchange or the Board of Trade to build a bridge over the Des Moines River at Eddyville. The same delegation desperately sought assurances from the management of the North Missouri Railroad that when graded and tied, the Iowa Central would receive the promised iron rail-and that when completed it would, in fact, be employed as a major segment of the St. Louis-St. Paul route. The editor of the St. Louis Republican urged support for the Iowa Central, but it was not forthcoming. ${ }^{28}$

Troubles multiplied. Difficulties had developed between the Iowa Central and Champlin, Balch \& Co. during the spring of 1868. The contract between them-which had promised the completion of the line to Cedar Falls-was dissolved. At about the same time the Iowa legislature passed a railroad bill which allowed a tax to be levied on townships and other governmental subdivisions. It seemed to augur well for the Iowa Central, but the law was soon declared unconstitutional. That proved to be a bruising blow, for it voided earlier commitments, and precluded any assistance at all from recalcitrant Poweshiek County where various geographic factions had long contested for the line. Furthermore, the memorial to Congress had been given an untimely death in Washington, and potential financiers in St. Louis began to shy away from the Iowa Central project. For that matter, the management of the North Missouri Railroad turned its energies to the completion of a route west of Moberly which eventually linked St. Louis with Kansas City, and at the same time placed its affections in the Hawkeye State with the rival St. Louis \& Cedar Rapids Railway. That road completed a line from a junction with the North Missouri Railroad at Coatsville, on the IowaMissouri border, to Moulton in December, 1868, extended it

${ }^{28}$ Cedar Falls Gazette, May 3, 1867, April 24, 1868; St. Louis Republican, an undated story reproduced in the Gazette, August 14, 1868. 
to Bloomfield in 1869, and reached Ottumwa in August, 1870. However, because of financial problems, the StL\&CR never reached its Cedar Rapids goal. Aspirations of the North Missouri and its St. Louis sponsors were thus short-circuited. ${ }^{29}$

The Iowa Central's death warrant was issued on June 23, 1869 ; it was on that day that the Central Railroad Company of Iowa (CRRCI) was born. Its goal, like that of the Iowa Central, was to span Iowa in a north-south direction, supplying the intervening link on a St. Louis-St. Paul route. But unlike the Iowa Central, the CRRCI represented the corporate growth of an established operation. Its earliest predecessor, the Eldora Railroad \& Coal Company, had completed a line between Ackley and Eldora in 1868. That company had evolved into the Iowa River Railway which extended the line southward from Eldora to Marshalltown in 1869. The CRRCI now proposed to absorb the Iowa River Railway, another road building north toward Minnesota from Ackley, and southern portions of the ill-fated Iowa Central-thus diverting the St. Louis-St. Paul road to a route farther west following the valley of the Iowa River. ${ }^{30}$

The North Missouri Railroad itself eventually fell on hard times, became a part of the Gould empire, later emerged as a part of the Wabash Railroad, and now is operated by the Norfolk \& Western Railway. The Minnesota Central ultimately became a part of the Milwaukee Road. The Cedar Falls \& Minnesota Railroad built on to the border of Minnesota from Waverly in $1868-1869$, and now is operated as a part of the Illinois Central Gulf Corporation. The Central Railroad Company of Iowa did complete a line across the state from north to

${ }^{29}$ Cedar Falls Gazette, April 3, 1868, April 16, 1869; Beard, "Local Aid to Railroads in Iowa," 24; Swartz, "The Wabash Railroad," 9; Wright, Peter Melendy, 245; Toledo [Iowa] Chronicle. December 7, 1950; Belcher, The Economic Rivalry Between St. Louis and Chicago, 125; State of Iowa, Report of the Board of Railroad Commissioners for the Year Ending June 30 , 1880 (Des Moines: State Printer, 1880), 246-247; Frank P. Donovan, Jr., "The Wabash in Iowa," The Palimpsest, Vol. XLV (October 1964), 369-374.

${ }^{30}$ Central Railroad of Iowa: Value and Security of Its Bonds (September 15, 1869). Available at Bureau of Economics Library, Association of American Railroads, Washington, D.C.; Eldora [Iowa] Ledger, August 1, 1868; On the Eldora Railroad \& Coal Company, see Donovan L. Hofsommer, "The Railroad and an Iowa Editor: A Case Study," Annals of Iowa, Vol. 41, No. 6 (Fall 1972), 1073-1103; J. S. McLintock, "History of the Corporate Organization and Construction of the Minneapolis \& St. Louis Railroad," (June 1917), 5. Available at the Hill Reference Library, St. Paul. 
south in 1871, and did achieve a connection with St. Paul. However, its desired direct connection with St. Louis did not materialize until 1899 . The CRRCI eventually went through a number of reorganizations, the property passed to the Minneapolis \& St. Louis Railroad in 1912, and became a part of the Chicago \& North Western System in 1960. The long hoped for St. Louis-St. Paul route was finally instituted through a series of connecting roads-in a few instances using some of this early trackage-but it never proved to be as important as it might have been, never broke the power of the Chicago-based roads, and represented a signal failure for St. Louis in its lethargic campaign of urban economic imperialism. ${ }^{31}$

The Iowa Central Railroad venture ended in a debacle. Over 100 miles of its projected road had been graded and bridged but no rail had been laid and no equipment had been purchased. The Central Railroad Company of Iowa did, of course, utilize portions of the Iowa Central grade near Oskaloosa. And other grades in Tama and Black Hawk Counties still can be seen today in a few places where the elements and the farmer's plow have not erased them. They stand mute in testimony to what might have been one of "the grandest railroad projects of the age!" 32

${ }^{31}$ Swartz, "The Wabash Railroad," 5-35; August Derleth, The Milwaukee Road: Its First Hundred Years (New York: Creative Age Press, 1948), 283; State of Iowa, Report of the Board of Railroad Commissioners for the Year Ending June 30, 1896 (Des Moines: State Printer, 1897), 221; McLintock, "History of the Corporate Organization and Construction of the Minneapolis \& St. Louis Railroad," 5; Donovan, "The Wabash in Iowa," 384.

${ }^{32}$ Toledo [Iowa] Chronicle, December 7, 1950; Wright, Peter Melendy, 246-248. 
Copyright of Annals of Iowa is the property of State of Iowa, by \& through the State Historical Society of Iowa and its content may not be copied or emailed to multiple sites or posted to a listserv without the copyright holder's express written permission. However, users may print, download, or email articles for individual use. 